\title{
The Socio-economic Implications of COVID-19: A Mini Systematic Review
}

Abdella Kosa Chebo ${ }^{1}$ Tadesse Weyuma Bulto ${ }^{2}$ and Asnake Gudisa Ede

1. Department of Management, Kotebe Metropolitan University, Addis Ababa, Ethiopia. Email: abdikosa@gmail.com or abdela.kossa@kmu.edu.et

2. Department of Environmental Management, Kotebe Metropolitan University, Addis Ababa, Ethiopia. E-mail: tadesseweyuma@kmu.edu.et or weyuma.tadesse@gmail.com

2. Department of Environmental Management, Kotebe Metropolitan University, Addis Ababa, Ethiopia. E-mail: astuasnegude@gmail.com

\begin{abstract}
The impact of SARS-CoV-2 virus is multidimensional and significantly affected the socio-economic dimensions of the world community. This paper is aimed to systematically review the socioeconomic aspects of COVID-19. From the review, a cyclical model that reveals and integrates the varieties of social and economic factors was developed. It revealed that the strict lockdown measures has contributed for reducing the spread of virus, while it extremely affects the socioeconomic dimensions. Further, the factors such as economic unemployment, household's income, financial markets, and psychological distress has been identified and discussed. Finally, the future research investigation should also give consideration to the forgotten aspects such as technological and politico-legal issues to build an integrated framework of COVID-19.
\end{abstract}

Keywords: COVID-19; Socio-economic; Systematic; Cyclical, Lockdown

\section{Introduction}

The COVID-19 pandemic is receiving intensive interest at all levels: political, economic, social, scientific, and in health care (Matias et al., 2020). Besides medical and technological challenges, societal, economic, psychological, and philosophical difficulties should be addressed in order to better approach the global crises (Rudnick, 2020). That is, the impact of this pandemic is not limited to the health crisis, but also with societal and economic crisis. There are a lot of socioeconomic crises that affects the human behavior (You et al., 2020). This is related with key important indices such as age, sex, ethnicity, education, socio-economic status, and geographic location is particularly pertinent (Yaya et al., 2020). For instance, the socio-economic status (SES)

indicated by income, education or occupation plays an important role in health outcomes (Yaya et al., 2020). Besides, the socio-cultural activities are restricted and the economy of countries has extremely impacted in the sectors such as tourism, trade, and transportation (Zeren \& Hizarci, 
2020). Moreover, the financial consequences related with unemployment and recession may reduce the satisfactions from the businesses and economies of countries (Sibley et al., 2020).

The lockdown and restrictions have high impacts on the economic conditions since countries are placing restriction on productions (Bellomarini, Benedetti, Gentili, Laurendi, \& Apr, 2020). As a result, the world economies are in a recession with a widespread of COVID-19 pandemic that hit the economic activities (Petric, 2020). There are many facts that indicated the down turn of economies. For instance, "the IMF warned that contraction and recovery of the world economy would be worse than anticipated. It also estimated a global GDP shrink of $3 \%$ this year" (Islam \& Fatema, 2020). Moreover, the pandemic leads to continuing loss of trillions of dollars due to the shutdown of businesses (Samuel et al., 2020). On the other hand, the weakened world economy is hoped to recover slowly as the virus gets more controlled (Faisal \& Nirmala, 2020). This requires quick government response to save huge economic recession in addition to saving lives. This is because, even though a healthy economy is depends on healthy people, extreme strict measures leads to extreme economic recession and depressions (Austermann et al., 2020). To overcome this challenges, governments are making decisions on the extent and the length of imposing restrictions, social distancing, shutting down of schools and industries (Anderson et al., 2020). However, it is vital for governments to balance between the effect of the epidemic, and the economic effect of the regulatory measures (Aspri et al., 2020). In general, there is a necessity to assess the economic effect of COVID-19 by a policy maker (Caraka et al., 2020).

A large related literature reveals that living through community-wide results in immediate risk to people's mental and physical health and social relationships (Sibley et al., 2020). There is dissatisfaction among people because of the lockdown, evidenced by the increasing number of protests, which indicates the presence of high desire to come back to work (Samuel et al., 2020). COVID-19 has highlighted inadequacies which were always present in our social and welfare services, such as the inadequate provision of medical care, food and benefit systems, and the lack of protections for homeless people, for squatters and for renters (Milligan, 2020). It is a serious condition that will cost hundreds of thousands of lives, and affect the psychology of people. Greater attitudes about the severity of COVID-19 were associated with more social distancing, disinfecting, and news monitoring, but also more hoarding (Oosterhoff, 2000). Therefore, all people behave very responsible during the COVID-19 pandemic, but radical social isolation of all 
population is not may be the best solution (Petric, 2020). This is because, the virus impacted the social and psychological well-being of the global community.

Consequently, Covid-19 have an impact on the various aspects of economy and social issues. However, the relationship between the various aspects associated with COVID-19 is not clear. Therefore, this study shows the socio-economic multifactor implications of COVID-19 for policy makers. The paper also explores the areas which are integrated with socio-economic aspects and under-researched including the unemployment, legal, and household income and uncovers their relevance. In general, no review paper is identified in the socio-economic implication of COVID19 and this review is among the first paper in reviewing the subject matter. In the next section further discussion on the existing theories on the socio-economic dimensions of COVID-19 were presented, followed by the methodology section. Then, in the fourth section the analysis of identified papers were presented, while the subsequent section is the discussion and conclusion section. Finally, the practical implications and future research direction has been offered.

\section{Theoretical Overview}

\subsection{Economic crisis and costs}

The Covid-19 outbreak results in a massive and far reaching economic burden for the whole economics including the USA, China, and Europe (Barua, 2020). It disrupts the functioning of global supply chains and the world economy, which is experiencing a contraction in production. Further, limited and restricted transport as well as global financial markets are also experiencing a significant downturn (Islam \& Fatema, 2020), which slower the global economic activity and reduces GDP greatly (Faisal \& Nirmala, 2020) and result in a global recession (Carlsson-Szlezak et al., 2020; Islam \& Fatema, 2020). The wide application of promoting healthy way of living practices to the community can break the chain of distribution and also reduce economic costs more quickly (Faisal \& Nirmala, 2020). For that reason, one can find the various opening levels that avert a sizeable number of deaths without determining an excessive damage to the economy (Aspri et al., 2020). Therefore, while saving lives is of course the utmost priority, governments must balance their responses to mitigate the negative consequences for businesses and their economy since a major depression may also cost further lives (Austermann et al., 2020).

\subsection{Social crises and disruptions}


Official control measures have been implemented to reduce the spread of COVID-19 (Matias et al., 2020), poses important societal challenges. For example, many people have been laid of work temporarily or permanently during the pandemic due to an insufficient workload (Rudnick, 2020). It's believed that social distancing considered as not appropriate since it impacts social stability and psychological impacts (Qian \& Jiang, 2020). The common misunderstanding by people poses unnecessary personal harm and public risk or alternatively unnecessary personal restriction and social disruption (Rudnick, 2020). Although disasters may increase support within the immediate family, there are increasing concerns that lockdown conditions are likely to increase domestic violence (Capaldi, Knoble, Shortt, \& Kim, 2012; Peterman, 2020; Taub, 2020; Sibley et al., 2020). Observed elevated intensity of the family violence during pandemics is associated with a range of factors including economic stress, disaster-related instability, increased exposure to exploitative relationships, and reduced options for support (Wang et al., 2020).

\subsection{Major socio-economic areas affected by COVID-19}

\subsubsection{Unemployment}

COVID-19 has caused a severe interruption in the functioning of businesses and institutions, leading to loss of employment [44] (Samuel et al., 2020). Some of the facts identified in this regard includes; "In their baseline scenario, unemployment increases by 12 percentage points of the labor force for a year, and it takes 4 years to get back to 3 percentage points above the starting point before the lockdown." (Aspri et al., 2020). Pickert (2020) reported that the U.S. government received an unparalleled increase in the number of people applying for jobless benefits with a total of 3.28 million within March 21 (Islam \& Fatema, 2020). Hutt (2020) also estimated that unemployment in the UK could rise by 2.1 million to 3.4 million due to this pandemic (Islam \& Fatema, 2020). According to the International Labor Organization (ILO), the global unemployment rate will increase by $3 \% 13 \%$, subsequently it will increase the underemployment and reduce the economic activities such as global tourism [45] (Samuel et al., 2020). Therefore, unemployment is one of the social and economic factor that is highly disrupted.

\subsubsection{Gender, age and education}

The vulnerability to psychological distress across populations in the COVID-19 pandemic could be attributable to various factors, including gender, social support, specific experiences with 
COVID-19 infection, length of isolation, and amount of exposure to the media (Brooks et al., 2020; Li et al., 2020; Oliveira \& Rossi, 2020). In terms of age, the elderly raise the fatality rate from COVID-19, while current smokers and urban dwellers raise the fatality rate the least (Szulczyk \& Cheema, 2020). Besides, while all humans are at risk of psychological harm when kept in isolation, the most vulnerable in these situations are children and adolescents, older adults,

minority groups, those from lower socio-economic groups, females, and people with preexisting mental health conditions (Shuja et al., 2020; Marčinko et al., 2020; Oliveira \& Rossi, 2020). Moreover, the fraction of poor people who usually have a low level of education are less likely to escape the pandemic (Ginsburgh et al., 2020).

\subsubsection{Household income and the disadvantages group}

The pandemic places the greatest inequalities and disparities in income as well as significant concentrations of marginalized, stigmatized, and disempowered populations, regardless of their geographic location, are also disproportionately at risk (CSWE, 2020; Hall, 2007; Kaiser Family Foundation, 2020; Rosoff, 2008; Wilson, 2020). Particularly, the most vulnerable to such disruptions are typically people who are already disadvantaged, such as those from lower socioeconomic strata, many retired people, homeless individuals and others (Rudnick, 2020). Ethnic and racial health disparities also continue to plague minority population resulting in worse health outcomes (Yaya et al., 2020). The community will relocate their spending budget to prevent the spread of this disease (Faisal \& Nirmala, 2020), which highly affects those with low income. The pandemic hits harder areas in socio-economic disadvantage today and will probably exacerbate disparities in the near future (Furceri et al., 2020; Ginsburgh et al., 2020). Generally, the most exposed households due to the health policies having imposed the lockdown are those with the lowest liquidity (Kaplan et al., 2020; Mihailov, 2020).

\subsubsection{Production and consumption balance}

Covid-19 epidemic has both aggregate demand and aggregate supply effects (Eichenbaum, Rebelo, \& Trabandt, 2020). According to Boone, Haugh, Pain, and Salins (2020), this pandemic will impact the global economy in three channels such as supply shock, demand shock, and uncertainty leading to reduced consumption of goods and services (Islam \& Fatema, 2020). The supply and demand effects work together to generate a large, persistent recession. (Eichenbaum, Rebelo, \& Trabandt, 2020). Since the outbreak of COVID-19, several business sectors have implemented 
shift systems for employees and even provided time off and rest time for them, which impacted on the decline in company production (Faisal \& Nirmala, 2020). The supply effect arises because the epidemic exposes people who are working to the virus and leads to less production while, the demand effect arises because the epidemic exposes people who are purchasing consumption goods to the virus that reducing their consumption (Eichenbaum, Rebelo, \& Trabandt, 2020). However, the demand profile changes depending on the infection levels in the population, which, in turn, is mitigated by the lockdown decisions (Çakmaklı et al., 2020). Later, after being hit by COVID-19, there is a need for adequate supply in the market due to high demand which at times can have a severe impact on several sectors and depends on how consumers behave later (Faisal \& Nirmala, 2020).

\subsubsection{Financial uncertainty and investment decisions}

The Covid-19 outbreak presents profoundly serious threats to the stability of the global financial system (McKibbin \& Fernando, 2020; Islam \& Fatema, 2020). The global financial markets are responsive to COVID-19 and makes the global stock index worse (Faisal \& Nirmala, 2020). Data analysis on daily COVID-19 cases and stock market returns for 64 countries demonstrated a strong negative return with increasing confirmed cases [43] (Samuel et al., 2020). Particularly, the stock

price decreases by $50 \%$ during the epidemic, but recovers quickly afterwards because the epidemic is a short lived labour supply shock (Toda, 2020; Caraka et al., 2020). Regarding the investment decision, it is understood that investing in the stock market is not the right option for investors (Zeren \& Hizarci, 2020). This might be because of the sizeably greater response of stock markets to COVID-19 (Baker et al., 2020; Mandel \& Veetil, 2020) and increasing risks in the global financial market (Samuel et al., 2020).

\subsubsection{Business sectors and size implications}

A hard blow from COVID-19 is reflected in the many industrial sectors that have struggled to recover (Faisal \& Nirmala, 2020). When shocks are concentrated in certain sectors, as they are during a shutdown in response to a pandemic, total demand and spending goes down given sectorial linkages (Çakmaklı et al., 2020). There will be a drastic decline in one industrial sector and a significant increase in other industrial sectors (Faisal \& Nirmala, 2020). The impacts are larger in the service industries due to social distancing which can be contrasted with the global recession. For instance, COVID -19 extremely effect the tourism industry (Islam \& Fatema, 2020). 
Further, several other sectors that provide services and consumption that involving personal contacts (ex. barbershop/ hair salon) are definitely affected economically (Faisal \& Nirmala, 2020). In terms of size, a common trait is observed in the introduction of measures to financially support families, SMEs, and temporally unemployed workers (Davola, 2020). Small and Medium Enterprises is one of the supporting factors of a countries' economy which will certainly be affected and requires immediate emergency fund allocation to provide liquidity for SMEs and their owners (Faisal \& Nirmala, 2020).

\subsubsection{Societal attitudes and behaviors}

Covid-19 is radically reshaping consumers' behavior with regards to future spending and significantly - repayment of previously stipulated loans (Davola, 2020). The intensity of the impact of the pandemic, the lockdown policies, and the behavioral response of agents beyond the regulations, have greatly impacted the economic production (Aspri et al., 2020). On the other hand, the public have good knowledge about the individual measures (physical distancing, proper hand hygiene, use of a face mask and respiratory etiquette) that will serve as the first line of defense against this disease (Salman et al., 2020). However, the common misunderstanding by lay people of what is robust evidence, may lead to their unsafe behavior or alternatively to their overly cautious behavior during the pandemic, which poses unnecessary personal harm and public risk or alternatively unnecessary personal restriction and social disruption, respectively (Rudnick, 2020). Further, despite the overall good knowledge and attitudes, it was worrisome that preventive practices related to COVID-19 were far from satisfactory (Salman et al., 2020).

\subsubsection{Societal and psychological well-being}

While the lockdown measures appear to have slowed the spread of the coronavirus, they also have revealed numerous gaps in the social safety nets available to vulnerable families and individuals (Council on Social Work Education [CSWE], 2020; Heath, 2020; 2020). Given this lockdown, the large-scale social threats typically undermine social well-being (Kaniasty \& Norris, 1993). Besides, some people may use the opportunity during the pandemic to disorganize society or to further restrict the general public and/or special social groupings that are considered by them as socially undesirable, which can disrupt personal and societal well-being (Rudnick, 2020). Besides, psychological and physiological processes operate in tandem to maximize equilibrium for each 
particular set of functions including subjective well-being (Matias et al., 2020). Further, the likely loss of trust in people who are physically close (and personally significant) to a person in case they are either infectious (while asymptomatic) may deeply disrupt people's mental well-being and functioning (Rudnick, 2020).

\section{Methodology}

\subsection{Study design}

We conducted a systematic mini-review of the literatures on multi-dimensional implications of COVID-19. This systematic mini-review used to recognize, evaluate, and synthesize the available literature since its comprehensive, explicit and reproducible approach. In defining the review scope, an expert from different fields of studies including health, environmental science, business, economics, and social psychology has been communicated and discusses the relevance of the review. Because of the multi-dimensional impacts of COVID-19, a thematic analysis was undertaken by identifying themes on the subject matter based on the suggestions provided by experts in different disciplines and the reviewer's experience. Then, these themes are used as a framework for analysis. The themes were identified different aspects under economic and social issues. In addition, we have included peer-reviewed articles, working papers, and special notes since it's a recent phenomenon and the number of articles published on the subject matter were not sufficient for review. On the other hand, pre-peer review articles and all other documents has been excluded in order to reduce the bias.

\subsection{Search strategy}

In order to avoid duplication of papers, in the first place, we have checked the availability of systematic review study in the subject of socio-economic implications of COVID-19. Then, the suitability of peer-reviewed scholarly works was assessed and found that it's relevant to provide a comprehensive scholarly work on this critical and timely issue. Therefore, the analysis was organized from the various implications of socio-economic aspects. Initially, we searched texts in Google scholar since the study is multidimensional, and downloaded all articles, discussion and working papers, and special notes from retrievals to June 2020. However, many articles that have no quality and published by predator journals were identified in the search and excluded from the review paper. Based on the identified themes, the results obtained from google scholar were summarized in table 1. 
Table 1: The selection criteria, process and eligibility of journal articles

\begin{tabular}{|llccccc} 
No & Dimensions & $\begin{array}{c}\text { Total } \\
\text { retrie } \\
\text { ved }\end{array}$ & $\begin{array}{c}\text { Based } \\
\text { on } \\
\text { quality }\end{array}$ & $\begin{array}{c}\text { Title \& } \\
\text { abstract based } \\
\text { relevance }\end{array}$ & $\begin{array}{c}\text { Full text } \\
\text { relevance }\end{array}$ & $\begin{array}{c}\text { Excluding other } \\
\text { documents except } \\
\text { peer reviewed articles }\end{array}$ \\
\hline 1 & $\begin{array}{l}\text { Economic } \\
\text { factors }\end{array}$ & 69 & 31 & 22 & 16 & 13 \\
\hline 2 & $\begin{array}{l}\text { Societal } \\
\text { factors }\end{array}$ & 116 & 43 & 28 & 15 & 9 \\
$\mathbf{3}$ & Total & $\mathbf{1 8 5}$ & $\mathbf{7 4}$ & $\mathbf{5 0}$ & $\mathbf{3 1}$ & $\mathbf{2 2}$ \\
\hline
\end{tabular}

After searched and downloaded articles from Google scholars based on exclusion criteria's, some works are excluded from the review based on the overall quality of journals and articles, title, abstract, and full text. The stages followed in the search strategies include, first, the term COVID19 is searched in combination with the above terms. Moreover, we have searched without spaces between the words in the quotation marks in order to identify both words together. Accordingly, 185 articles were identified in the first search by defining the publication year as 2020 . Next, articles that are not peer-reviewed were removed. This is followed by reviewing the identified papers based on their title and abstracts depends on its relevance to the scope of the study. In this case, the title, abstract, or full-text review which is not related to the study topic is eliminated. Finally, working papers, discussion papers, special series notes, and short communications were excluded. Moreover, the search strategy and selection process are summarized in table 1 above.

\subsection{Data Extraction, Synthesis, and analysis}

Table 1 indicates that COVID-19 has various implications on issues of business-economics and social aspects. After the scholars from these disciplines were communicated, data were extracted by two independent reviewers. We have identified and removed the duplicated articles manually. Moreover, we have documented the literature findings and evaluation of results to ensure the study quality. Then, the synthesis was made to obtain necessary findings in relation to the various socioeconomic aspects related with COVID-19 and to build a comprehensive big picture by focusing on the relevant and necessary ideas. For analysis, a qualitative research method is used to analyze and discuss the theoretical aspects related to the socio-economic implications of COVID-19. From this, we compared and contrast the logic and arguments of many scholars to provide conclusions based on the synthesized arguments. 


\section{Analysis}

The extent of COVID-19 effects are different among different sectors (eg, service sector is highly affected), firm sizes (small firms were more affected), social groups (disadvantages and minorities are more affected) and etc. Regarding the demographic factors, Acemoglu et al. (2020) considers structural differences in infections for distinct age groups that affect lockdown policies and economic costs (Çakmaklı et al., 2020). In general, the various economic areas affected by the outbreak of COVID-19 includes; Global disaster (Gupta, 2020), tourism industry (Oruonye \& Ahmed, 2020), supply chain disruptions (Oruonye \& Ahmed, 2020; Tang, Gaoshan, \& Ahonsi, 2020) food insecurity (Cosgrove, 2020), shortage of raw materials (Tang et al., 2020), drop in productivity and efficiency (Raja, Lennes, \& Biddinger, 2020). These economic difficulties lead to loss of employment which further affects food security. This directly leads to the social crisis.

The papers identified have related to many socio-economic factors including social behavior and attitudes (Ling \& Ho, 2020, Sibley et al., 2020, Salman et al., 2020), psychological distress (Zhang et al., 2020, Sibley et al., 2020, Oliveira \& Rossi, 2020, Rudnick, 2020), addictive disorders (Marsden, et al., 2020), disadvantages and minorities (Algarin et al., 2020, Opara et al., 2020, Yaya et al., 2020, Ginsburgh et al., 2020), infection level (Tomar \& Gupta, 2020, Cássaro \& Pires, 2020, Qian \& Jiang, 2020, Aluga, 2020), demand and supply (Matias et al., 2020), societal well-being (Sibley et al., 2020), economic disruption (Austermann et al., 2020), business sectors (Oruonye \& Ahmed, 2020, Islam \& Fatema, 2020, Mihailov, 2020, Caraka et al., 2020), supply chain (Faisal \& Nirmala, 2020, Mandel \& Veetil, 2020), economic costs (Mandel \& Veetil, 2020), financial markets (Abubakar, 2020, Zeren \& Hizarci, 2020), and economic uncertainties (Eichenbaum, Rebelo, \& Trabandt, 2020, Baker et al., 2020). In general, the socio-economic impacts of COVID19 were indicated in figure 1 and table 2. 
Table 2: Summary of objective and findings of the studies

\begin{tabular}{|c|c|c|}
\hline Authors & Objectives & Findings \\
\hline $\begin{array}{l}\text { Ling \& Ho, } \\
2020\end{array}$ & $\begin{array}{l}\text { To analyze and explain the effects of COVID-19 on } \\
\text { social behavioral reactions. }\end{array}$ & $\begin{array}{l}\text { Most individuals prevailing over societal collective interest amid the pandemic have } \\
\text { been prevalently observed. They also incentivize others to act selfishly, if no } \\
\text { restrictions are imposed. }\end{array}$ \\
\hline $\begin{array}{l}\text { Zhang et al., } \\
2020\end{array}$ & $\begin{array}{l}\text { To identify the characteristics of psychological distress } \\
\text { across populations affected by the COVID- } 19 \text { pandemic. }\end{array}$ & $\begin{array}{l}\text { The study revealed differential levels of psychological distress in patients who } \\
\text { experienced COVID-19 infection, individuals under quarantine, and the general } \\
\text { public. }\end{array}$ \\
\hline $\begin{array}{l}\text { Marsden, et al., } \\
2020\end{array}$ & $\begin{array}{l}\text { To assess the ways of mitigating and learning from the } \\
\text { impact of COVID-19 infection on addictive disorders }\end{array}$ & $\begin{array}{l}\text { Emotions are likely to place us at increased risk of a range of unhealthy behaviors. } \\
\text { Some drug and alcohol services will innovate-providing novel ways of delivering } \\
\text { harm reduction. }\end{array}$ \\
\hline $\begin{array}{l}\text { Tomar } \& \\
\text { Gupta, } 2020\end{array}$ & $\begin{array}{l}\text { Proposing data-driven estimation methods like long short- } \\
\text { term memory (LSTM) \& curve fitting for prediction and } \\
\text { effect of preventive measures like social isolation \& } \\
\text { lockdown on the spread. }\end{array}$ & $\begin{array}{l}\text { The prediction of various parameters obtained by the proposed method is accurate } \\
\text { within a certain range and will be a beneficial tool for administrators and health } \\
\text { officials. By these preventive measures, spread of the virus can be reduced } \\
\text { significantly. }\end{array}$ \\
\hline $\begin{array}{ll}\text { Cássaro } \quad \& \\
\text { Pires, } 2020\end{array}$ & $\begin{array}{l}\text { Presenting a simple model to follow the evolution of the } \\
\text { COVID-19 pandemic in different countries. }\end{array}$ & $\begin{array}{l}\text { It is almost impossible to predict based on the initial CV-19 cases how the pandemic } \\
\text { will evolve. This approach can serve as a valuable tool for investigating how } \\
\text { protective measures are changing the evolution of the pandemic. }\end{array}$ \\
\hline $\begin{array}{l}\text { Matias et al., } \\
2020\end{array}$ & $\begin{array}{l}\text { To review the science of human needs and to make } \\
\text { preliminary recommendations concerning necessary self- } \\
\text { care focusing on exercise. }\end{array}$ & $\begin{array}{l}\text { In the vast majority of cases, individuals in social isolation have no access to mental } \\
\text { healthcare. An in-built system of homeostasis can help rebalance activity, thought \& } \\
\text { feeling. }\end{array}$ \\
\hline $\begin{array}{l}\text { Sibley et al., } \\
2020\end{array}$ & $\begin{array}{l}\text { This article presents a comprehensive analysis institutional } \\
\text { trust, attitudes toward the nation and government, physical } \\
\text { and psychological health, and subjective well-being. }\end{array}$ & $\begin{array}{l}\text { People in the lockdown group reported higher trust in science, politicians, and police, } \\
\text { higher levels of patriotism, and higher rates of mental distress compared to people in } \\
\text { the pre lockdown group. Results were confirmed in within-subjects analyses. }\end{array}$ \\
\hline $\begin{array}{l}\text { Yaya et al., } \\
2020\end{array}$ & $\begin{array}{l}\text { Examines how racism, segregation and inequality, now } \\
\text { emerge as a monumental COVID-19 challenge. }\end{array}$ & $\begin{array}{l}\text { COVID-19 has exposed the strong association between race, ethnicity, culture, } \\
\text { socioeconomic status and health outcomes. }\end{array}$ \\
\hline $\begin{array}{l}\text { Oliveira \& } \& \\
\text { Rossi, } 2020\end{array}$ & $\begin{array}{l}\text { In this review, we hope, through comparative behavioral } \\
\text { analysis, to avoid, mitigate and alleviate social stress in } \\
\text { humans. }\end{array}$ & $\begin{array}{l}\text { By minimizing stress, the most rudimentary emotions, similar between humans } \\
\text { and mice, but concient-rationalized in the human and promote the improvement of } \\
\text { the human being's elevated quality of life, even in social isolation/quarantine. }\end{array}$ \\
\hline $\begin{array}{l}\text { Qian \& Jiang, } \\
2020\end{array}$ & $\begin{array}{l}\text { The aim of this article is to discuss the social distancing } \\
\text { measures for COVID-19. }\end{array}$ & $\begin{array}{l}\text { After a series of social distancing measures, there are } 309 \text { cities with zero cases and } \\
34 \text { cities with confirmed cases in China as of April 13,2020. }\end{array}$ \\
\hline Rudnick, 2020 & $\begin{array}{l}\text { Presents social, psychological and philosophical } \\
\text { reflections regarding the current pandemic and beyond. }\end{array}$ & $\begin{array}{l}\text { Highly exposed individuals and particularly vulnerable populations (eg. health care } \\
\text { providers, socially disadvantaged etc, are addressed as requiring special attention. }\end{array}$ \\
\hline $\begin{array}{l}\text { Chakraborty \& } \\
\text { Maity, } 2020\end{array}$ & $\begin{array}{l}\text { Describes the impact of COVID-19 on society and global } \\
\text { environment, and the possible ways in which the disease } \\
\text { can be controlled has also been discussed therein. }\end{array}$ & $\begin{array}{l}\text { Almost all the nations are struggling to slow down the transmission of the disease by } \\
\text { testing \& treating patients, quarantining suspected persons through contact tracing, } \\
\text { restricting large gatherings, maintaining complete or partial lock down etc. }\end{array}$ \\
\hline Aluga, 2020 & $\begin{array}{l}\text { Highlighting the preparedness, response, transmissibility } \\
\text { of Covid-19 and proposes intuitions to manage COVID-19 }\end{array}$ & $\begin{array}{l}\text { The confirmed cases will continue to increase exponentially if no drastic measures is } \\
\text { taken. }\end{array}$ \\
\hline
\end{tabular}




\begin{tabular}{|c|c|c|}
\hline $\begin{array}{l}\text { Oruonye \& } \\
\text { Ahmed, } 2020\end{array}$ & $\begin{array}{l}\text { This study has examined the potential impact of covid-19 } \\
\text { pandemic on tourism development in Nigeria. }\end{array}$ & $\begin{array}{l}\text { Covid-19 is already worsening the unemployment situations, resulting in loss of } \\
\text { substantial revenue to the government, increasing incidence of poverty among others. }\end{array}$ \\
\hline $\begin{array}{l}\text { Islam } \& \\
\text { Fatema, } 2020\end{array}$ & $\begin{array}{l}\text { Examines the potential macroeconomic effects of Covid- } \\
19 \text { on the tourism sector of Europe, US, and China as well } \\
\text { as provides policy suggestions in light of previous works. }\end{array}$ & $\begin{array}{l}\text { The global tourism sector is geocentric and the tourism sector of EU countries } \\
\text { is interdependent. The study also finds strong domestic tourism in the USA and China } \\
\text { whereas domestic tourism in EU countries is not that strong. }\end{array}$ \\
\hline $\begin{array}{l}\text { Austermann et } \\
\text { al., } 2020\end{array}$ & $\begin{array}{l}\text { Analyzes selected Asian \& European countries along the } \\
\text { degree of strictness when shutting down economic \& } \\
\text { social life. }\end{array}$ & $\begin{array}{l}\text { Governments across Asia, Europe, and indeed worldwide almost show a concerted } \\
\text { action when it comes to the timing of taking measures against the common global } \\
\text { threat of the virus. }\end{array}$ \\
\hline $\begin{array}{l}\text { Faisal } \quad \& \\
\text { Nirmala, } 2020\end{array}$ & $\begin{array}{l}\text { This paper tries to map the economic impacts that are } \\
\text { generally experienced by countries in the world affected } \\
\text { by the pandemic. }\end{array}$ & $\begin{array}{l}\text { A simple policy that can be easily implemented by everyone, requires awareness and } \\
\text { compliance for all elements of society so that all can implement it which is useful to } \\
\text { break the chain of distribution of COVID-19, to help the world economy recover. }\end{array}$ \\
\hline $\begin{array}{l}\text { Caraka et al., } \\
2020\end{array}$ & $\begin{array}{l}\text { Assesses the effect of large scale restrictions on the } \\
\text { economic growth during COVID-19 pandemic in } \\
\text { Indonesia. }\end{array}$ & $\begin{array}{l}\text { There are significant differences of retail, grocery and pharmacy, and residential } \\
\text { mobility before and during the COVID-19 pandemic. During the pandemic there are } \\
\text { severe economic losses, industry, companies, and real disruptions. }\end{array}$ \\
\hline $\begin{array}{l}\text { You et al., } \\
2020\end{array}$ & $\begin{array}{l}\text { The purpose of this paper was to assess the distribution of } \\
\text { COVID- } 19 \text { morbidity rate in association with social and } \\
\text { economic factors and discuss the implications for urban } \\
\text { development that help to control infectious diseases. }\end{array}$ & $\begin{array}{l}\text { Increasing population density, construction land area proportion, value-added of } \\
\text { tertiary industry per unit of land area, total retail sales of consumer goods per unit of } \\
\text { land area, public green space density, aged population density were associated with } \\
\text { an increased COVID-19 morbidity rate. }\end{array}$ \\
\hline $\begin{array}{l}\text { Abubakar, } \\
2020\end{array}$ & $\begin{array}{l}\text { This paper identifies the adverse effect of corona virus to } \\
\text { businesses across the globe. }\end{array}$ & $\begin{array}{l}\text { The values of the stock market fall to negative, while that of gold and oil tumbled } \\
\text { significantly. Transportations \& travel companies, businesses in the hospitality } \\
\text { industry, \& industrial production companies experience significant drop in patronage. }\end{array}$ \\
\hline $\begin{array}{l}\text { Zeren \& } \\
\text { Hizarci, } 2020\end{array}$ & $\begin{array}{l}\text { Aimed to reveal the possible effects of Covid }-19 \\
\text { Coronavirus epidemic on stock markets. }\end{array}$ & $\begin{array}{l}\text { All stock markets examined with total death act together in the long run. It is } \\
\text { considered as one of the optimal option for investors to avoid investments in stock } \\
\text { markets, turn to investment in gold markets. }\end{array}$ \\
\hline $\begin{array}{l}\text { Eichenbaum et } \\
\text { al., } 2020\end{array}$ & $\begin{array}{l}\text { We extend the canonical epidemiology model to study } \\
\text { the interaction between economic decisions \& epidemics. }\end{array}$ & $\begin{array}{l}\text { The competitive equilibrium is not socially optimal. The best simple containment } \\
\text { policy increases the severity of the recession \& saves half a million lives in U.S. }\end{array}$ \\
\hline
\end{tabular}




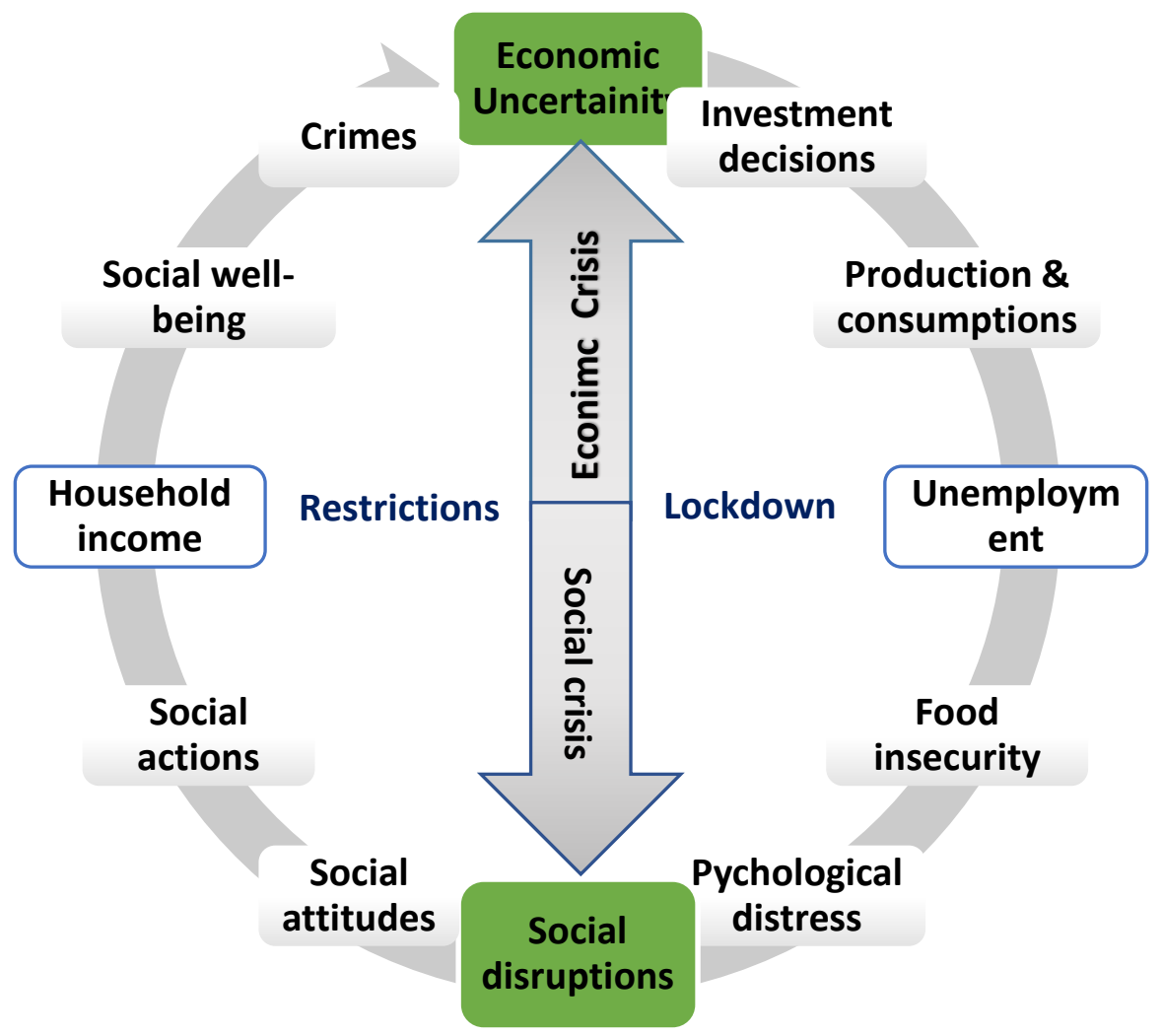

Figure 1: Socio-economic implication of COVID-19

The occurrence of COVID-19 brings severe disruptions in the business organizations, which further leads to unemployment, reduced income, labor market disruptions, and increasing in distress (Samuel et al., 2020). More specifically, the sequential socio-economic influence is integrated and difficult to locate its starting point. Then, we have seen the sequential impacts as a circle, which influences each other. The pandemic leads to the presence of high economic uncertainty. This economic uncertainty may have different implication on different economic sectors. For instance, the tourism sector is highly impacted because of the restriction on the transport and peoples movement. According to Faisal \& Nirmala, (2020), there are other service sectors which are highly impacted such as beauty salon and food shopping in restaurants. The economic uncertainty has also different impact on the different sizes of firms. That is, SMEs are more impacted and requires emergency fund, relaxation of installment payments, and cutting interest rates compared to the larger firms. 


\section{Discussion and conclusions}

COVID-19 brings various challenges including; economic difficulty and social crisis. Therefore, the socio-economic implication is one of the highest area that has been affected by the pandemic. This may bring many social and economic crises. Particularly, COVID-19 is bringing economic crisis from the lock down that hinders economic activities, and loss of income from shut down of business operation. This may also be associated with low production and less income from tourism and related industries. Besides, there are high costs associated with the outbreak of COVID-19. This may be because of less availability of raw material, which may lead to shutting down of many businesses and trades. Particularly, small firms are more vulnerable since they have less capacity to survive in this tough economic situation. It's also known that the level of uncertainty from the pandemic is higher, because of social isolation and physical distancing. The presence of high economic uncertainty has negative implications on the investment decision by investors. It also has implications on differentiating the economic sectors which are suitable/not suitable for investment in this pandemic time. In this regard, investing in the stock market is considered as unsuitable alternative with the increasing of COVID-19 case and death rates (Zeren \& Hizarci, 2020), since the pandemic is badly affects the financial markets and the stock market. That is because, investment decisions are highly responsive for the pandemic (Caraka et al., 2020). Therefore investment decision is the decision that requires critical investigation in this period of pandemic.

Investing only in the selected areas of investment and the overall economic uncertainty leads to the imbalance between production and consumption and/or demand and supply. In terms of sectors, the concentration of shocks in some sectors, makes the demand and expenditure reduced (Çakmaklı et al., 2020), particularly related to tertiary goods. Boone, Haugh, Pain, and Salins (2020) stated that the pandemic has impacted in three channels such as demand shock, supply shock, and uncertainty that leads to less consumption. On the other hand, the level of consumption is dependent on the amount of infected people. With the occurrence of COVID-19, many businesses have used shifts and gives time offs for workers, which reduces the production. Moreover, Faisal \& Nirmala, (2020) revealed that due to increased demand during severe effect, there will be a need for sufficient supply. That is, the panic among consumers and producers can change the current pattern of consumptions. 
In balancing the supply with demand, many industries are reducing their workers that brings unemployment. The high rate of unemployment has high implications on the overall economic and social crisis of countries. The high rate of unemployment leads to food insecurity, which further has implications on the psychological distress. Besides, financial impacts, the pandemic has implications on the psychological aspects. For instance, Rudnick, (2020) related unemployment with disturbed psychological well-being, poverty, crime, and the like. Therefore, the lockdown causes psychological and societal problems, more on the most vulnerable peoples including children and elders, minorities, and women (Marčinko et al., 2020). Further, the vulnerability to psychological distress associated with various factors, including gender, social support, specific experiences with COVID-19 infection, length of isolation, and amount of exposure to the media (Zhang et al., 2020). This crisis and disruptions requires tough governmental and policy decisions. Though the tough policy decision severely affected the social activities.

The overall economic crisis and psychological distress among societies creates high social disruptions. Socially, the effects are associated with quarantining, large gathering restrictions, and lock down (Chakraborty \& Maity, 2020) that hinders social advancement. Such pandemic effects are believed to have influenced human behavior (such as issues of panic buying and noncompliance with government orders and law) (Ling \& Ho, 2020). Moreover, the social disruption has contributed to changing social attitudes and behaviors. The society perceived the lockdown as a personal restriction and brings social disruptions. They also perceive that social distancing leads to depression and anxiety, and therefore, it's not suitable (Qian \& Jiang, 2020).

The negative attitude among the societies highly changed the social actions. That is, there is a high anxiety that the lockdown increased stresses and alcohol consumption, which will raise the violence (Sibley et al., 2020). In this regard, the increase in violence is related with several factors including "economic stress, disaster-related instability, increased exposure to exploitative relationships, and reduced options for support" (Wang et al., 2020). Accordingly, with the increment of loss of life, social disorders will happen. Also, the closure of educational institutions may lead to long term societal difficulties, while in the short term, domestic violence which may require political and legal decisions may rise.

Restrictions on societal actions, unemployment, and overall social disruptions has contributed for the reduction of household's income. Particularly, this pandemic affects highly the socio-economic 
disadvantaged (Ginsburgh et al., 2020) including, ethnic minorities (Yaya et al., 2020), those from lower socioeconomic strata and retired people (Faisal \& Nirmala, 2020; Rudnick, 2020). Besides, places exhibiting the greatest inequalities and disparities in income as well as significant concentrations of marginalized, stigmatized, and disempowered populations, regardless of their geographic location, are also disproportionately at risk (Santiago \& Smith, 2020). The reduction in the household income also have worsen the social stability and further social advancement. The loss of income that happened because of social restrictions, unemployment may increase the amount of crimes. The unemployed have more affected because of less income. Therefore, the reduction of household's income from the crisis has negative implications on societal wellbeing. That is, the disorganization and limits can interrupt the societal well-being. The overall damage on social well-being leads individuals to involve in various crimes. For instance, Rudnick, (2020) stated that there are peoples that used the pandemic as an opportunity to disorganize the society, particularly those they consider as socially undesirable. In return, the increasing number of crimes leads to uncertainty (Both economic and societal). Therefore, the socio-economic implications of COVID-19 is cyclical and difficult to locate the starting and ending points.

\section{Practical implication}

At this critical time, while saving lives is of course the utmost priority, governments must balance their responses to mitigate the negative consequences for businesses, economy, and the society since a major depression may also cost further lives (Austermann et al., 2020). Hence, the governments should try to look for the socio-economic impacts of COVID-19, in order to respond through a coordinated strategy to reduce the consequences of the epidemic. Besides, to improve the health system and build the strong facilities and infrastructures which may support to respond effectively, it's crucial to protect both the economic and societal well-being. Therefore, it's recommended that the governments and policy makers consider these multidimensional frameworks simultaneously rather than considering a single aspect in order to effectively respond to the COVID-19 outbreak. Particularly, they have to work on how safely work and come back to the operations. The governments should also give considerations for the highly affected groups by the crisis including, the small firms (eg. providing credit access), and disadvantages and minorities (eg. Providing free access to health and other services).

\section{Limitations and Future Research}


This study is not out of limitations. First, in this study we made a systematic review with secondary data sources in order to undertake comprehensive analysis. That evidence seems to be largely understood to mean research-based evidence, and not necessarily experiential, implementationbased evidence from the field (Raja et al., 2020). Therefore, the future researchers should focus on obtaining original data's and conduct experimental researches. Second, the study of socioeconomic aspects of COVID-19 is wider in scope. However, it's necessitated to conduct a review since there are no sufficient publications in each specific subject matters. For future researchers, we recommend to conduct their study on specific subjects such as unemployment, household incomes, and financial deregulations.

Third, the political and legal decisions are required in every aspects of the socio-economic effects of COVID-19. In the search we made, we are unable to get relevant study that related the COVID19 outbreak with the legal and political aspects. Therefore, the political and legal aspects should be studied and integrated with the socio-economic implications of COVID-19. The major areas that requires flexible decision includes domestic violence, informal settlements (Cosgrove, 2020), irregular migrants (Nanthini, 2020), institutions and regulations (Auener et al., 2020). Consequently, future researchers should critically give consideration to these factors in association with the implications of COVID-19.

Fourth, the technological perspectives have also paramount importance in the socio-economic, health system, and overall environment, even if it's under researched. For instance, the dramatic experience of the global Covid-19 pandemic has highlighted the great difficulty of effectively monitoring patients with existing information systems (Hueber, 2020). Timely and integrated data are not only key in the fight against COVID-19, while digital technologies are useful also for prevention and surveillance measures [27]. Accordingly, the various areas to be considered and requires further clarification in the future research should include; health block chain (Hueber, 2020), Digital applications (Auener et al., 2020), Future nano-technologies and active filters

(Gaddi \& Capello, 2020). All this specific issue should be considered and studied in association with socio-economic implications of COVID-19 in the future research.

\section{References}

Abubakar, Ahmed. (2020). Coronavirus (COVID-19): Effect and Survival Strategy for Businesses. Journal of Economics and Business, Vol.3, No.2, 661-671. 
Aluga, M. A. (2020). Coronavirus Disease 2019 (COVID-19) in Kenya: Preparedness, response and transmissibility. Journal of Microbiology, Immunology and Infection, 2019(April), 20192021. https://doi.org/10.1016/j.jmii.2020.04.011

Aspri A., Beretta E., Gandolfi A., and Wasmer E. (2020). Mortality Containment vs. Economics Opening: Optimal Policies in a Seiard Model.

Auener, S., Id, D. K., Id, E. W., Id, S. V. D., \& Jeurissen, P. (2020). Perspective COVID-19 : A Window of Opportunity for Positive Healthcare Reforms, (x), 1-4. https://doi.org/10.34172/ijhpm.2020.66

Austermann F., \& Shen W., \& Slim A. (2020). Governmental responses to COVID-19 and its economic impact: a brief Euro-Asian comparison. Asia Europe Journal, Policy Brief.

Baker S R., Bloom N., Davis S J., and Terry S J. (2020). COVID-Induced Economic Uncertainty. NBER Working Paper No. 26983.

Bellomarini, L., Benedetti, M., Gentili, A., Laurendi, R., \& Apr, A. I. (2020). COVID-19 and Company Knowledge Graphs: Assessing Golden Powers and Economic Impact of Selective Lockdown via AI Reasoning *, 31.

Boone, L., Haugh, D., Pain, N., \& Salins, V. (2020). Tackling the fallout from COVID-19. In R. Baldwin \& B. W. di Mauro (Eds.), Economics in the Time of COVID-19: A VoxEU.org Book, Centre for Economic Policy Research, London.

Çakmaklı C., Demiralp S., Kalemli-Özcan S., Yesiltas S., and Yildirim M A. (2020). Covid-19 and Emerging Markets: Epidemiological Multi-Sector Model for A Small Open Economy with an Application to Turkey. NBER working paper 27191.

Caraka R E., Y. Lee, R. Kurniawan, R. Herliansyah, P.A. Kaban, B.I. Nasution, P.U. Gio, R.C. Chen, T. Toharudin, B. Pardamean. (2020). Impact of COVID-19 large scale restriction on environment and economy in Indonesia. Global J. Environ. Sci. Manage. 6(SI): 65-84.

Cdr Surg, B., \& SaurabhCapt, S. R. (2020). Going Viral - Covid - 19 Impact Assessment : A Perspective beyond Clinical Practice, 9-12. https://doi.org/10.4103/jmms.jmms

Chakraborty, I., \& Maity, P. (2020). COVID-19 outbreak : Migration, effects on society, global environment and prevention. Science of the Total Environment, 728, 138882. https://doi.org/10.1016/j.scitotenv.2020.138882

Cosgrove, C. (2020). Impact of COVID-19 on Slums and Informal Settlements, (April).

Davola A. (2020). From the Black swan, to the Snowball. Risks of Covid-19 pandemic for consumer credit scores in the lack of a harmonized regulatory intervention. Retrieved from; https://ssrn.com/abstract=3604031 
Eichenbaum M S., Rebelo S., and Trabandt M. (2020). The Macroeconomics of Epidemics. NBER working papers.

Faisal M., and Nirmala M P. (2020). COVID-19 and Economic Policy Options: What Should the Government do? Jurnal Inovasi Ekonomi., 05(02), Page 45-52.

Gaddi, A. V., \& Capello, F. (2020). Particulate does matter: is Covid-19 another air pollution related disease?, (April). https://doi.org/10.13140/RG.2.2.22283.85286/2

Gupta, S. (2020). Covid-19 a pandemic viral pneumonia is a global disaster in 2020, 3(1), 16-20.

Hueber, O. (2020). Blockchain and health for a health blockchain compatible with Covid-19 data management, 11.

Islam M., and Fatema F. (2020). Covid-19 and Sustainable Tourism: Macroeconomic Effect and Policy Comparison among Europe, the USA and China. Asian Business Consortium 10(1), 53-60.

Ling, G. H. T., \& Ho, C. M. C. (2020). Effects of the Coronavirus (COVID-19) Pandemic on Social Behaviours: From a Effects of the Coronavirus (COVID-19) Pandemic on Social Behaviours : From a Social Dilemma Perspective, (May).

Mandel A., and Veetil V. (2020). The Economic Cost of COVID Lockdowns: An out-ofequilibrium analysis. https://ssrn.com/abstract=3588421

Marčinko, D., Jakovljević, M., Jakšić, N., Bjedov, S., Mindoljević, A. (2020). The Importance of Psychodynamic Approach during COVID-19 Pandemic. Psychiatr Danub, 32(1):15-21.

Matias T., Dominski F H., and Marks D F. (2020). Human needs in COVID-19 isolation. Journal of Health Psychology, Vol. 25(7), $871-882$.

Mihailov A. (2020). Quantifying the Macroeconomic Effects of the COVID-19 Lockdown: Comparative Simulations of the Estimated Galí-Smets-Wouters Model. Economic Analysis Research Group (EARG) Discussion Paper No. 2020-07.

Milligan, R. T. (2020). COVID-19 and Social Reproduction, 6.

Nanthini, S. (2020). Impact of COVID-19 : Can Irregular Migrants Cope? (May).

Oliveira G. M and Rossi M.I.D. (2020). COVID-19, Social Isolation and Human Stress Comparative Behavior \& Welfare. New York Science Journal 13(5), 14-22.

Oosterhoff, B. (2000). Psychological Correlates of News Monitoring, Social Distancing, Disinfecting, and Hoarding Behaviors among US Adolescents during the COVID-19 Pandemic, 20.

Oruonye, E. D., \& Ahmed, Y. M. (2020). An Appraisal of the Potential Impacts of Covid-19 on Tourism in Nigeria, 1(1), 32-41. https://doi.org/10.22158/jetr.v1n1p32 
Petric, D. (2020). Negative mental health effects of COVID-19 pandemic and panic, 1-6.

Pieter, B., \& Andrée, J. (2020). Incidence of COVID-19 and Connections with Air Pollution Exposure Evidence from the Netherlands, 30.

Qian M., \& Jiang J. (2020). COVID-19 and social distancing. Journal of Public Health: From Theory to Practice. https://doi.org/10.1007/s10389-020-01321-z

Raja, A. S., Lennes, I. T., \& Biddinger, P. D. (2020). Creating a COVID-19 surge clinic to offload the emergency department, (xxxx), 3-5. https://doi.org/10.1016/j.ajem.2020.04.057

Rudnick A. (2020). Social, Psychological, and Philosophical Reflections on Pandemics and Beyond. Societies 10(42).

Salman Muhammad., Zia Ul Mustafa, Noman Asif, Haider Abbas Zaidi, Khalid Hussain, Naureen Shehzadi, Tahir Mehmood Khan, Zikria Saleem. Knowledge, attitude and preventive practices related to COVID-19: a cross-sectional study in two Pakistani university populations. Drugs \& Therapy Perspectives. https://doi.org/10.1007/s40267-020-00737-7

Samuel J., Md. Mokhlesur Rahman, G. G. Md. Nawaz Ali, Yana Samuel, Alexander Pelaez, Peter H.J. Chong, and Michael Yakubov. (2020). Feeling Positive about Reopening? New Normal Scenarios from COVID-19 Reopen Sentiment Analytics. https://doi.org/10.1101/2020.06.01.20119362

Santiago A M., \& Smith R J. (2020). Community practice, social action, and the politics of pandemics. Journal of Community Practice 28(2), 89-99.

Sentell, T., \& Vamos, S. (2020). Interdisciplinary Perspectives on Health Literacy Research Around the World : More Important Than Ever in a Time of COVID-19. Environmental Research and Public Health, 1-13.

Sibley C G et al., (2020). Effects of the COVID-19 Pandemic and Nationwide Lockdown on Trust, Attitudes toward Government, and Well-Being. American Psychological Association. http://dx.doi.org/10.1037/amp0000662

Tang, K., Gaoshan, J., \& Ahonsi, B. (2020). Sexual and reproductive health (SRH): a key issue in the emergency response to the coronavirus disease ( COVID- 19 ) outbreak, 17-19.

Wang, C. et al. (2020) Immediate Psychological Responses and Associated Factors during the Initial Stage of the 2019 Coronavirus Disease (COVID-19) Epidemic among the General Population in China. Int J Environ Res Public Health.

Yaya S, Yeboah H, Charles CH, Out A., and Labonte R. (2020). Ethnic and racial disparities in COVID-19- related deaths: counting the trees, hiding the forest. BMJ Global Health 5: e002913 
You H., Wu X. and Guo X. (2020). Distribution of COVID-19 Morbidity Rate in Association with Social and Economic Factors in Wuhan, China: Implications for Urban Development. Int. J. Environ. Res. Public Health 17, 3417.

Zeren F., and Hizarci A E. (2020). The Impact of COVID-19 Coronavirus on Stock Markets: Evidence from Selected Countries. MUFIDER, 3(1), 78 - 84

Zhang D., M. Hu, and Q. Ji, "Financial markets under the global pandemic of covid-19," Finance Research Letters, p. 101528, 2020.

Zhang, J., Lu, H., Zeng, H., Zhang, S., Du, Q., Jiang, T., \& Du, B. (2020). Brain, Behavior, and Immunity. Brain Behavior and Immunity, (April), 1-2. https://doi.org/10.1016/j.bbi.2020.04.031

Zhong L., L. Mu, J. Li, J. Wang, Z. Yin, and D. Liu, "Early prediction of the 2019 novel coronavirus outbreak in the mainland china based on simple mathematical model," IEEE Access, vol. 8, pp. 51 761-51 769, 2020. 